протоколу до неї» від 16.12.2009 [Електронний ресурс]. - Режим доступу : URL :http://zakon4.rada.gov.ua/ laws/show/1767-175. Закон України «Про реабілітацію інвалідів в Україні» у редакції від 09.12.2012 [Електронний ресурс]. - Режим доступу : URL :http://zakon4.rada.gov.ua/laws /show/ 2961-15 6. Закон України «Про внесення змін до законодавчих актів з питань загальної середньої та дошкільної освіти щодо організації навчально-виховного процесу» від 06.07.2010 [Електронний ресурс]. Режим доступу: URL :http://zakon4.rada.gov.ua/ laws/show/2442-17 7. Лист МОН «Щодо посадових обов'язків асистента вчителя» № 1/9 675 [Електроннийресурс]. - Режим доступу : URL :http://osvita.ua/ legislation/Ser_osv/32125/8. Наказ МOH «Про затвердження Положення про дистанційне навчання» від 25.04.2013№ 466 [Електронний ресурс]. - Режим доступу : URL : http://zakon4.rada.gov.ua/laws/show/z0703-13 9. Наказ МОН «Про створення умов щодо забезпечення права на освіту осіб 3 інвалідністю» від 02.12.2005 № 691[Електронний ресурс]. - Режим доступу: http://www.kmu.gov.ua/control/uk/publish/artic le?art_id=25374378\&cat_id=244314797 10. Наказ МОН «Про затвердження Концепції розвитку інклюзивної освіти» від 01.10.2010 № 912[Електронний ресурс]. - Режим доступу : URL : http://osvita.ua/legislation/Ser_osv/9189/ 11. Постанова КМУ «Про затвердження Державної цільової програми «Національний план дій з реалізації Конвенції про права інвалідів» на період до 2020 року» від 1 серпня 2012 р. № 706 [Електронний ресурс]. - Режим доступу : URL : http://zakon4.rada.gov.ua/laws/show/706-2012-п 12. Розпорядження КМУ «Про затвердження плану заходів щодо запровадження інклюзивного та інтегрованого навчання у загальноосвітніх навчальних закладах на період до 2012 року» у редакції від 03.12.2009 № 1482-р [Електронний ресурс]. - Режим доступу : URL :http:/www.kmu.gov.ua/kmu/control/uk/cardnpd 13. Статут Державного вищого навчального закладу «Криворізький національний університет» [Електронний pecypc]. - Режим доступу : URL : http://knu.edu.ua/14. Указ Президента України «Про першочергові заходи щодо створення сприятливих умов життєдіяльності осіб 3 обмеженими фізичними можливостями» від 01.06.2005 [Електронний ресурс]. Режим доступу : URL : http://zakon4.rada.gov.ua/laws/show/900/2005

\title{
РЕАЛІЗАЦІЯ МЕТОДИКИ ФОРМУВАННЯ ГОТОВНОСТІ МАЙБУТНІХ МЕНЕДЖЕРІВ ДО ЗАСТОСУВАННЯ ІНФОРМАЦІЙНИХ ТЕХНОЛОГІЙ У ПРОФЕСІЙНІЙ ДІЯЛЬНОСТІ
}

Пшенична О.С. Реалізація методики формування готовності майбутніх менеджерів до застосування інформаційних технологій у професійній діяльності.

У статті розглянута характеристика наскрізної методики формування готовності майбутніх менеджерів до використання інформаційних технологій у професійній діяльності. На основі якісного аналізу процесу підготовки студентів установлено вплив кожного прийому та методу на компоненти готовності майбутніх управлінців, який представлений графічно - у вигляді матриці впливу. 
Ключові слова: методика, метод, методичний прийом, інформаційні технології, готовність, компоненти готовності, матриця впливу.

Пшеничная Е. С. Реализация методики формирования готовности будущих менеджеров к использованию информационных технологий в профессиональной деятельности.

В статье рассмотрена характеристика сквозной методики формирования готовности будущих менеджеров к использованию информационных технологий в профессиональной деятельности. На основе качественного анализа процесса подготовки студентов установлено воздействие каждого приема и метода на компоненты готовности будущих управленцев, что представлено графически - с помощью матрицы влияния.

Ключевые слова:методика, метод, методический прием, информационные технологии, готовность, компоненты готовности, матрица влияния.

Pshenichna O. S. Implementation of methods of formation of readiness of future managers to use information technology in professional activities.

Description of through methods of formation of readiness of future managers to use information technology in professional activities is considered in the article. Based on a qualitative analysis of the process of preparation of students it is identified the impact of each approach and method on preparedness components of future managers, what is presented graphically - using the matrix of influence.

Key words: methods, method, methodical approach, information technology, readiness, readiness components, the matrix of influence.

На сучасному етапі в Україні відбувається становлення системи освіти, яка зорієнтована на входження до єдиного світового освітнього простору, що кардинально впливає на процес підготовки фахівців з вищою освітою. Саме тому професійна підготовка спеціалістів у системі вищої школи вимагає докорінного іiі оновлення в умовах реалізації Національної доктрини розвитку освіти України у ХXI столітті та виконання Законів України «Про освіту», «Про вищу освіту». Це стосується і майбутніх менеджерів, підготовка яких має бути спрямованою на розвиток фахівців, здатних ефективно здійснювати управління підприємством. Зважаючи на те, що інформаційні технології (IT) підвищують ефективність управління, необхідно вдосконалити процес навчання майбутніх фахівців 3 менеджменту використанню IT. Для цього необхідно впровадити в навчальний процес науково обгрунтовану методику формування готовності до застосування IT.

Проблема засвоєння інформаційних технологій актуальна на сучасному етапі. Ї̈ визначальні положення представлені в працях М. Жалдака, Н. Морзе, 3. Сейдаметової, С. Семерікова та ін. Основні дослідження підготовки майбутніх фахівців до застосування інформаційних технологій здійснюються в контексті навчання майбутніх учителів (Г. Генсерук, М. Кадемія, Л. Петухова, О. Снігур та ін.), економістів (О. Гончарова, Л. Дибкова, Н. Праворська та ін.), юристів (О. Бурцева, М. Шерман) та менеджерів (Т. Коваль, К. Могилевська). Більшість дослідників задля підвищення якості підготовки майбутніх фахівців до застосування інформаційних технологій пропонують удосконалити методику вивчення IT. Майже у всіх розглянутих нами публікаціях автори акцентують увагу на доцільності використаннятаких активних методів навчання, як: «мозковий штурм» (К. Могилевська [4], О. Снігур [6]); аналіз конкретних ситуацій (Г. Генсерук [1], 
О. Снігур [6]); $\quad$ метод п проектів (М. Головань [2], $\quad$ Т. Коваль [3]); тренінг (К. Могилевська [4]); ігрові методи навчання (Т. Коваль [3], О. Снігур [6]); імітаційне моделювання (К. Могилевська [4]).

Усі названі дослідники працюють над удосконаленням методики підготовки фахівців до застосування IT, однак упроваджують ці методи у вивчення дисциплін блоку «Інформатика». Ми ж уважаємо, що ефективна методика формування готовності майбутніх менеджерів до використання інформаційних технологій має бути наскрізною і охоплювати вивчення не тільки дисциплін загальнонаукової, але й загальноекономічної та професійно зорієнтованої підготовки.

Метою статmі є перевірка ефективності впровадженої у наскрізну підготовку майбутнього фахівця 3 управління експериментальної методики формування готовності майбутнього менеджера до застосування IT у професійній діяльності.

Підготовка фахівців з управління у нашому дослідженні здійснювалася протягом чотирьох етапів: пропедевтичного, базового, системного та інтеграційнопрофесійного [5, с. 146-147]. Для реалізації методики підготовки майбутніх фахівців 3 МО до використання інформаційних технологій було розроблено: комплекс навчальнометодичного забезпечення дисциплін загальнонаукової, загальноекономічної та професійно зорієнтованої підготовки; навчальні посібники, методичні рекомендації та лабораторні тренінги 3 цих дисциплін; комплекс кейсів і завдань, спрямованих на засвоєння інформаційних технологій; зміст проектів 3 навчальних курсів; імітаційна та ділова ігри.

На пропедевтичному етапі формування готовності студентів-менеджерів до застосування інформаційних технологій складалося 3 теоретичного та практичного навчання. Основними методами і прийомами підготовки на цьому етапі були лекціявізуалізація - лекція, тренінг і«дуель»- лабораторні заняття, метод проектів та імітаційна гра «Застосування IT у розробленні бізнес-плану підприємства»самостійна робота студента (СРС). Підготовка майбутніх менеджерів організацій на базовому етапі здійснювалася на лекціях, лабораторних і практичних заняттях та в умовах СРС. Методами та прийомами, впровадженими в навчально-виховний процес, були: на лекціях - лекція-візуалізація, на лабораторних заняттях - тренінги і ділова гра «Планування та організація навчальної діяльності в середовищі Microsoft Office Outlook», на лабораторних і практичних заняттях - case-study, в умовах CРC - метод проектів. На системному етапі організаційними формами навчання були практичні заняття та самостійна робота студентів, а методами - «мозковий штурм» та case-study. Під час інтеграційно-професійного етапу вивчення дисциплін професійно зорієнтованої підготовки проводилося на практичних і лабораторних заняттях та в умовах СРС. Методами формування готовності до застосування IT у професійній діяльності були case-study, імітаційне моделювання та метод проектів. Кожний прийом і метод, запропонований нами, має однакову структуру: 1) підготовча стадія ознайомлення із завданням та вимогами; 2) основна стадія - реалізація методу; 3) заключна стадія - захист завдання, підведення підсумків, оцінювання студентів.

Особливістю розробленої методики $є$ інтеграція різних прийомів і методів підготовки. Наприклад, на базовому етапі вивчення дисципліни «Комп’ютерний практикум» здійснювалося в такій послідовності: тренінг «Розроблення системи керування базою даних» $\rightarrow$ кейс «Звітування керівникові» $\rightarrow$ проект «Розроблення інформаційної системи засобами MS Access» $\rightarrow$ тренінг «Застосування інформаційних технологій в управлінні» $\rightarrow$ кейс «Безліч ділових документів - один метод підготовки».

Готовність до застосування IT має компонентну структуру, а саме: складається 3 мотиваційно-ціннісного, індивідуально-психологічного, когнітивного, професійно- 
діяльнісного, комунікативного і рефлексивного складників [5, с. 143], і методика іiі формування має на меті розвиток кожного 3 цих компонентів. Для перевірки ефективності запропонованих методів і прийомів здійснено якісний аналіз процесу підготовки майбутнього менеджера до застосування IT.

Задля надання теоретичних відомостей використовувалися лекції-візуалізації, які сприяли підвищенню рівня теоретичних і практичних знань з IT, оскільки в них повною мірою використовувалися приклади, які демонстрували роботу алгоритму виконання дій у середовищі того чи того додатка. Наші спостереження за аудиторією засвідчили, що такі лекції викликали у студентів емоційну реакцію, заохочували та зацікавлювали їх до вивчення IT. Наведене підтверджує безпосередній уплив методу на розвиток когнітивного й мотиваційно-ціннісного компонентів готовності. Особливістю цього методу стало те, що він демонстрував можливості мультимедіа-документів задля подання та передавання візуальної інформації, а отже, опосередковано сприяв розвитку професійно-діяльнісного та комунікативного компонентів, оскільки майбутні менеджери безпосередньо не брали участі в розробленні презентацій.

На лабораторних заняттях основним методом навчання став тренінг. Завдання до тренінгів були призначені для відпрацювання в нових умовах уже засвоєних умінь і навичок роботи в середовищі додатка. Вони мали міжпредметний характер, професійне спрямування і передбачали прийняття рішення на основі отриманих результатів. У деяких випадках це були лише окремі вправи, але в більшостізагальне завдання. Тренінг як метод підготовки фахівців мав значення для розвитку мотиваційно-ціннісного компонента. Також практична робота в додатках сприяла покращенню індивідуально-психологічного, когнітивного, професійно-діяльнісного і рефлексивного компонентів.

У ході реалізації прийому «дуель» студентам пропонувалося самостійно розробити завдання із засвоєної теми; на наступному занятті два «дуелянти» обмінюються своїми завданнями. Один студент представляв завдання, а другий його розв'язував. Потім вони обмінювалися ролями. «Секундантами», які відстежували помилки, були викладач та одногрупники «дуелянтів». Прийом «дуель» дав змогу покращити навчальнопізнавальну мотивацію (мотиваційно-ціннісний компонент), закріпити практичні знання та вдосконалити їх мобільність (когнітивний компонент). Він сприяв розвитку творчого потенціалу майбутнього фахівця (професійно-діяльнісний), оскільки самостійна підготовка завдань- процес дуже креативний. У ході розроблення цих завдань опосередковано розвивався індивідуально-психологічний компонент.

Метод проектів реалізовувався шляхом виконання індивідуальних завдань. На початковому етапі роботи над проектом студентам пропонували приклади вдалих проектів, які потім аналізувалися. Це сприяло розвитку рефлексивного компонента готовності. Ознайомлення з проектами, розробленими студентами, засвідчило, що в ході практичного навчання вони добре засвоїли додатки. Метод проектів став важливим для мотиваційно-ціннісного компонента, оскільки сприяв розвитку кожного виду мотивації. Виконання завдань у середовищі додатка вплинуло на формування відповідних здібностей (індивідуально-психологічний), теоретичних знань (когнітивний), практичних умінь розв’язувати проблеми управління (професійно-діяльнісний).

Ігрові методи представлені імітаційною грою «Застосування IT у розробленні бізнес-плану підприємства» та діловою грою «Застосування інформаційних технологій в управлінні». Ігровий простір імітаційної гри було забезпечено за допомогою засобів комп'ютерного зв'язку - електронної пошти та «Skype». У процесі обговорення за етапами гри учасники висловлювали свої пропозиції щодо проблеми, 
здійснювали обмін думками, приймали рішення. Під час гри керівник створював атмосферу, яка сприяла розвитку у студентів творчої активності, формуванню в них впевненості. Для стимулювання розумової активності студентів демонструвалася неоднозначність ситуації, яка створювалася за допомогою висловлювань «Що буде, якщо ...», «Уявіть собі, що...» тощо.

Виконання завдань тренінгу «Мережні технології» супроводжувалося діловою грою. Метою іiі було ознайомлення студентів з можливостями програми планування робочого часу та розвиток у них умінь застосовувати IT мережного зв'язку для ділової комунікації. Ігровий процес полягав у випробуваннях на посаду менеджера «підприємства». Завдяки діловій грі робота студентів була організованою, що дало їм можливість виконати лабораторні роботи вчасно. На етапі підбиття підсумків респонденти зазначили, що не очікували такого ефекту. Отже, iii впровадження сприяло засвоєнню IT для виконання професійних умінь: планування особистого часу, організації праці, здійснення поточного впорядкування роботи.

Загалом же ігрові методи сприяли покращенню мотиваційно-ціннісного ставлення до IT, розвитку здібностей до застосування IT у роботі менеджера, формуванню знань і практичних умінь (зокрема комунікативних й аналітичних). Отже, цей метод безпосередньо вплинув на розвиток усіх компонентів готовності майбутнього фахівця з управління до використання IT.

У процесі реалізації методу case-study учасники об'єдналися у групи по 5-6 осіб, кожна 3 яких аналізувала ситуацію, пропонувала відповіді на запитання та представляла розв'язання проблеми. Виконання ситуативного завдання «Безліч ділових документів - один метод підготовки» дещо відрізнялося від звичайної схеми. Відповідно до завдань майбутнім фахівцям було запропоновано окреслити управлінські проблеми, для вирішення яких можна використовувати технологію злиття документів. Ця особливість вплинула на процедуру реалізації методу: кейс був запропонований майбутнім фахівцям напередодні, а пропозиції обговорювалися в аудиторії протягом 10 хв. Студентами було запропоновано 21 ситуацію, тематика яких була різноманітною і свідчила про розуміння майбутніми управлінцями перспектив застосування офісних додатків для розроблення ділових паперів. Реалізація методу casestudy здійснювалася на системному етапі шляхом колективного розроблення кейсів. Ці завдання відрізнялися різноманітними фактологічними та статистичними матеріалами, наочністю їх представлення (таблиці, діаграми, графіки, малюнки), відповідністю змісту ситуації основній ідеї кейса. Назви цих завдань розкривали сутність ситуації, представленої в кейсі. Підготовлені ситуативні завдання розв'язувалися в аудиторії та оцінювалися студентами. Найкращим був обраний кейс «Інвестиційна компанія». Робота над ситуаційними завданнями продемонструвала підвищення рівня всіх компонентів готовності. На думку майбутніх фахівців, аналіз професійних ситуацій надав їм можливість ознайомитися зі сферами застосування інформаційних технологій під час розв'язання професійних проблем. У цілому ж цей метод безпосередньо вплинув на всі компоненти готовності.

Задля виявлення можливостей різноманітних додатків для розв'язання проблем управління були проведені 30-хвилинні «мозкові штурми». На початковому етапі студенти ознайомлювалися із завданням. Основний етап поділявся на кілька фаз. На першій висувалися ідеї щодо розв'язання проблеми, які записувалися на дошці. Друга фаза передбачала аналіз пропозицій та відмову від хибних. I насамкінець ідея реалізовувалася на комп'ютері, завдяки чому визначалося найбільш ефективне рішення. На заключному етапі проводилося підбиття підсумків, аналізувалися 
запропоновані ідеї та здійснювалася рефлексія. Запропоновані студентами підчас «мозкових штурмів» ідеї розв'язання задач були оригінальними, продуктивними та характеризувалися різноманіттям. Загалом реалізація «мозкового штурму» на системному етапі сприяла безпосередньому розвитку всіх компонентів готовності і опосередковано - індивідуально-психологічного.

Професійне вміння прийняття рішень передбачає багатоваріантний аналіз, тому для підготовки застосовувалося імітаційне моделювання. Основна увага зверталася на те, що комп'ютер надає змогу швидко, ефективно й точно обчислювати параметри різноманітних варіантів рішень на основі розробленої моделі. Студентам було запропоновано розробити базу знань для прийняття рішення про доцільність продажу акцій фірми та за допомогою моделі виявити всі значення, за яких вигідно продавати акції. Спочатку студенти створили базу знань та базу даних для побудови експертної системи, потім побудували «дерево рішень». Розроблення системи прийняття рішень та реалізація іiі моделі засвідчили наявність у студентів сформованих умінь виконання дій у різних додатках. На думку більшості представників експериментальних груп, використання методу імітаційного моделювання засвідчило, що комп'ютер $\epsilon$ найбільш ефективним засобом для обчислення показників моделі, на основі яких обирається найбільш прибутковий варіант. Загалом метод імітаційного моделювання надав змогу покращити мотиваційно-ціннісний, індивідуально-психологічний, когнітивний, професійно-діяльнісний та рефлексивний і опосередковано вплинув на розвиток комунікативного компонентів.

Наведена характеристика формування готовності й узагальнений аналіз дали змогу виявити безпосередній та опосередкований уплив відповідних прийомів та методів на формування компонентів готовності майбутнього менеджера до застосування IT, завдяки чому побудовано матрицю впливу педагогічних прийомів і методів на формування компонентів готовності (рис. 1). Ця матриця ілюструє можливості кожного прийому та методу, тому у процесі підготовки до застосування ІТ у професійній діяльності їх слід ураховувати.

\begin{tabular}{|c|c|c|c|c|c|c|}
\hline \multirow{2}{*}{$\begin{array}{c}\text { Педагогічні прийоми } \\
\text { та методи формування } \\
\text { готовності }\end{array}$} & \multicolumn{6}{|c|}{ Компонент } \\
\hline & $\begin{array}{c}\text { Мотиваційно- } \\
\text { ціннісний }\end{array}$ & $\begin{array}{l}\text { Індивідуально- } \\
\text { психологічний }\end{array}$ & $\begin{array}{l}\text { Когні- } \\
\text { тивний }\end{array}$ & $\begin{array}{l}\text { Професійно- } \\
\text { діяльнісний }\end{array}$ & $\begin{array}{c}\text { Комуні- } \\
\text { кативний }\end{array}$ & $\begin{array}{l}\text { Рефлек- } \\
\text { сивний }\end{array}$ \\
\hline \multicolumn{7}{|l|}{ Лекція-візуалізація } \\
\hline \multicolumn{7}{|l|}{ Тренінг } \\
\hline \multicolumn{7}{|l|}{ Прийом «дуель» } \\
\hline \multicolumn{7}{|l|}{ Метод проектів } \\
\hline \multicolumn{7}{|l|}{ Ігрові методи } \\
\hline \multicolumn{7}{|l|}{ Case-study } \\
\hline \multicolumn{7}{|l|}{ «Мозковий штурм» } \\
\hline Імітаційне моделювання & & & & & & \\
\hline
\end{tabular}

Рис. 1 Матриця впливу педагогічних прийомів та методів на формування компонентів готовності

Отже, формування готовності до застосування інформаційних технологій у професійній діяльності фахівця з менеджменту є складним, тривалим та інтегрованим 
процесом, який відбувається протягом чотирьох років навчання. Надана якісна характеристика методики дала змогу визначити вплив кожного з методів та прийомів на розвиток компонентів готовності. Представлену методику підготовки майбутнього менеджера до застосування IT у професійній діяльності ми розглядаємо як систему, яка $\epsilon$ частиною підготовки фахівців 3 управління до професійної діяльності. Перспективу подальших досліджень вбачаємо у проведенні кількісного аналізу результатів формувального експерименту.

\section{Література}

1. Генсерук Г. Р. Підготовка майбутніх учителів фізичної культури до застосування інформаційних технологій у професійній діяльності : автореф. дис. на здобуття наук. ступеня канд. пед. наук : спец. 13.00.04 «Теорія і методика професійної освіти» / Г. Р. Генсерук. - Тернопіль, 2005. - 20 с.2. Головань М. С. Використання методу проектів у процесі вивчення інформатики та комп'ютерної техніки в економічному вузі/ М. С. Головань// Теорія та методика навчання математики, фізики, інформатики : зб. наук. пр. : у 3 т. - Кривий Ріг : Вид-во НМетАУ, 2003.Вип. 3. - Т. 3: Теорія та методика навчання інформатики. - С. 67-71.3. Коваль Т. І. Теоретичні та методичні основи професійної підготовки з інформаційних технологій майбутніх менеджерів-економістів : автореф. дис. на здобуття наук. ступеня д-ра пед. наук : спец. 13.00.04 «Теорія і методика професійної освіти»/ Т. І. Коваль. - К., 2008. - 44 с.4. Могилевская Е. В. Профессиональная подготовка будущих менеджеров с использованием имитационного моделирования на основе информационных технологий : дис. ... канд. пед. наук : 13.00 .08 / Екатерина Владимировна Могилевская. - Ставрополь, 2006. - 193 с.5. Пшенична О. С. Модель підготовки майбутнього менеджера організацій до застосування інформаційних технологій / О.С. Пшенична // Вісник Запорізького національного університету: Педагогічні науки. - 2012. - № 2. - С. 142-147.6. Снігур О. М. Формування вмінь використовувати засоби інформаційних технологій у майбутній професійній діяльності вчителя початкової школи : автореф. дис. на здобуття наук. ступеня канд. пед. наук : спец. 13.00.09 «Теорія навчання» / О. М. Снігур. - К., 2007. - 22 с.

УДК 378.14

Антоніна Рибалко

\section{ОПТИМІЗАЦІЯ ВИКЛАДАННЯ ВИЩОЇ МАТЕМАТИКИ В СУЧАСНИХ УМОВАХ}

Рибалко А. П. Оптимізація викладання вищої математики в сучасних умовах.

У статті запропоновано структуру навчального процесу, що дозволить викладачам вищої математики ефективно комбінувати традиційні та інноваційні методи і засоби навчання. Розглянуто особливості впровадження сучасних освітніх технологій 3 урахуванням специфіки предмета. Визначено шляхи оптимізації навчального процесу, обгрунтовано доцільність застосування відповідних методів у викладацькій практиці.

Ключові слова:вища школа, викладання вищої математики, інноваційні методи і засоби навчання, інформаційні комп'ютерні технології, пакети прикладних програм.

Рыбалко А. П. Оптимизация преподавания высшей математики в современных условиях.

В статье предложена структура учебного процесса, позволяющая преподавателям высшей математики эффективно комбинировать традиционные и 